\title{
The Robustness of Balinese Hindu Sacred Art in the Face of Hegel's Theory 'The Death of Art'
}

\author{
Abdulloh Fuadi* ${ }^{*}$ \\ 1 Universitas Islam Negeri Mataram, Indonesia; e-mail: abdulloh.fuadi@uinmataram.ac.id \\ * Correspondence
}

Received: 2021-09-28; Accepted: 2021-11-25; Published: 2021-12-31

\begin{abstract}
The integration of art as an integral part of the sacred rituals of Balinese Hindu worship to this day makes the discussion of Hegel's thoughts on art is interesting. This paper attempts to discuss Hegel's theory as confronted with the sacred Balinese Hindu art. The most basic reason for the death of art is that since romantic, art has lost its subject matter. The process of dematerialisation in art gave rise to Hegel's very famous adage; the death of art. Art loses subject matter because of the limited media to express the complexity of the Absolute Spirit. However, the sacredness of Balinese Hindu art has been deeply guarded by the Balinese people. Various concepts and classifications are made to maintain its sacredness, such as the concept of belief, the concept of sekala-niskala, the concept of tri hita karana, the concept of kala patra village, the concept of karmaphala, and the concept of taksu/jengah. There is also a classification of sacred and profane arts. It is made by Balinese Hindus to maintain the sacredness of art itself. Through the art of wali and bebalih, the Balinese Hindu art maintains its subject matter concerning the complexity of the Absolute Spirit, as suggested by Hegel. Based on library research, the paper argues that the unique concept of Balinese Hindu, which may represent the wealth of indigenous religions in Indonesia, concerning sacred art can maintain its uniqueness in the global discourse arena and be able to respond creatively to contemporary challenges.
\end{abstract}

Keywords: Balinese Hindu; Hegel's Theory; Sacred Art; The Death of Art.

\begin{abstract}
Abstrak: Integrasi seni sebagai bagian integral dari ritual sakral ibadah penganut Hindu Bali hingga saat ini membuat pembahasan mengenai pemikiran Hegel tentang seni menjadi menarik. Tulisan ini berupaya membahas teori Hegel yang dikonfrontasikan dengan seni sakral Hindu Bali. Alasan paling mendasar dari kematian seni adalah bahwa sejak era romantik, seni telah kehilangan subjeknya. Proses dematerialisasi dalam seni memunculkan pepatah Hegel yang sangat terkenal; kematian seni. Seni kehilangan subjeknya karena keterbatasan media untuk mengungkapkan kompleksitas Ruh Absolut. Namun, kesakralan seni Hindu Bali telah sangat dijaga oleh masyarakat Bali. Berbagai konsep dan klasifikasi dibuat untuk menjaga kesakralannya, seperti konsep kepercayaan, konsep sekala-niskala, konsep tri hita karana, konsep desa kala patra, konsep karmaphala, dan konsep taksul jengah. Ada juga klasifikasi seni sakral dan profan. Hal ini dilakukan oleh umat Hindu Bali untuk menjaga kesakralan seni itu sendiri. Melalui seni wali dan bebalih, seni Hindu Bali mempertahankan subjeknya tentang kompleksitas Ruh Absolut, seperti yang dikemukakan oleh Hegel. Berdasarkan penelitian kepustakaan, makalah ini berargumen bahwa konsep unik umat Hindu Bali yang dapat mewakili kekayaan agama-agama asli di Indonesia tentang seni sakral mampu mempertahankan keunikannya sendiri di kancah wacana global dan mampu menjawab tantangan kontemporer secara kreatif.
\end{abstract}

Kata Kunci: Hindu Bali; Kematian Seni; Seni Sakral; Teori Hegel. 


\section{Introduction}

On a global scale, the world's Hindus are estimated at approximately 800 million people. Most of them live in India, which is about 650 million people, or about $85 \%$ of the world's Hindu population. India is the home of Hindu spiritualism (Weber, 1958, p. 3). Hinduism has evolved from the combined imaginations of many individuals and groups, Hindu and non-Hindu. It covers many traditions, myths, institutions, and rituals. It has the power and diversity to capture the imaginations of Hindus and non-Hindus alike. Therefore, it has the capacity to challenge all preconceived ideas about what a religion is (Knott, 1998, p. 118). Hinduism absorbed many ideas from other religions as it spread to southern India, like a great river through which many tributaries flow to it. Mahatma Gandhi (18691948) also said about the nature of this religion: Hinduism is a living organism, which may evolve and may be damaged and subject to the laws of nature. One and the essentially indivisible, which has grown into a great tree with countless branches (Keene, 2006, p. 11).

Gandhi's statement seemed to emphasise how rich Hinduism is. There are many variants in it, not only in the scale of quantity but also in quality. Various concepts also appear in every Hindu community with their characteristics and uniqueness. Likewise with Balinese Hinduism. This community has its uniqueness that may not be found in Hindu communities in other areas. Some even questioned the religious identity of Balinese Hindus and said that it is more of the result of political compromise to be accepted and recognised by the Indonesian government and as the response to challenges from monotheistic religions, particularly Islam (McDaniel, 2010; Picard, 2011; Wijaya, 2014).

Based on the above statement, the concepts developed in Balinese Hinduism known today as Modern Balinese Hinduism is essentially something new. It is a blend of Hindu teachings and Balinese beliefs. The influence of Hinduism reached the archipelago in the first century. There are at least four theories that analyse the various routes of the arrival of Hinduism to the archipelago. The theory seemed to use the metaphor of the caste system. First, is the Vaishya theory. This theory says that Hinduism came with traders and merchants from India, whose voyages often included intermarriage with Indonesians. The second is the Kshatriya theory. This theory says that defeated warriors and soldiers fled India with their followers to take refuge and build alternative strongholds in Indonesia. Third, is the Brahmana theory. This theory says that priests and missionaries from India spread the religion, which was accepted because these people were believed to possess supernatural knowledge and power. Fourth, is the theory of Bhumiputra ("native son" or nationalist). This theory says that Indonesians visited India, liked the culture, and brought back religious ideas (McDaniel, 2010, p. 95).

One of the Balinese Hindu concepts is using art as part of sacred rituals of worship, not only as an ornament, decoration, or accompaniment of worship but also as an integral part of worship itself. Balinese Hindus consciously make art as a way of experiencing abstract experiences when they come into contact with forces outside themselves. Rudolf Otto calls this experience The Numinous (Otto, 1950, p. 7), which is a non-rational and non-sensory experience or feeling. The divine experiences experienced by the adherents of this religion are varied. The diversity of experience not only on its substance but also its expression. Balinese Hindus are very rich in expressing it, particularly by using art as one of their articulations. Up to now, this sacred art is still practiced by the Balinese Hindus.

On the other hand, George Wilhelm Friedrich Hegel (1770-1831) in his philosophical structure on the logic of historical development of the universe, placed art dialectically with religion and philosophy. This triad (art, religion, philosophy) is an attempt to capture and reveal the consciousness of the Absolute Spirit. Based on the arrangement of this Hegel's triad, a very famous adage emerged; 'the death of art'. The echo of this adage has caused controversy to this day (Carter, 1980). Then a new adage emerged as a continuation in the contemporary era; 'the end of art'. After all, the philosophical structure compiled by Hegel invites other thinkers to contribute the results of their rational reflection in uncovering the complexities of human civilisation (Bertram, 2017; J. Miller, 2012).

The integration of art as an integral part of the sacred rituals of Balinese Hindu worship to this day makes the discussion of Hegel's thoughts on art is interesting. This paper attempts to discuss Hegel's theory of 'the death of art' as confronted with the sacred Balinese Hindu art. Through the exploration I made based on library research, I argue that the unique concept of Balinese Hindu, which may 
represent the wealth of indigenous religions in Indonesia, concerning sacred art can maintain its uniqueness in the global discourse arena and be able to respond creatively to contemporary challenges. The data obtained in this research are from library materials, such as books, and journal articles. Two criteria in the material selection are in consideration: a) the principle of recency; b) the principle of relevance (Harahap, 2014, p. 69). These two criteria are used in selecting various reference sources, both those related to the figure discussed in this study and those related to the theme of research.

\section{Hegel's Dialectic of Art}

Georg Wilhelm Friedrich Hegel (1770-1831) had addressed many lectures on several topics. Some of the lectures are compiled under several works, such as Aesthetics: Lectures on Fine Art. Volume I (Hegel, 1975a), Aesthetics: Lectures on Fine Art. Volume II (Hegel, 1975b), Phenomenology of Spirit (Hegel, 1977), The Philosophy of History (Hegel, 1991), The Science of Logic (Hegel, 2010), and so forth. Before reviewing Hegel's dialectical theory on art, the basic ideas of Hegel's philosophical structure will be described, in order to understand the position of the art dialectic among other structures within the broad framework of the philosophy he built.

The basic idea of Hegel's philosophical structure is that all realities are a process of becoming Spirit self-conscious. What is meant by Spirit is the Absolute Spirit. Religious people call this kind of Spirit God. Absolute Spirit or God is similar to another term, Rational Spirit. The whole process of selfconsciousness of the Spirit evolves through a dialectical process; thesis, antithesis, and synthesis. This triad became Hegel's basic style in compiling his philosophy, therefore all his thoughts were organised dialectically.

The structure of Hegel's Philosophy in such a way is closely related to the creation myth, that in the beginning there was only the Pure Spirit which had a Universal nature and One. The Pure Spirit is also called the Pure Mental State. Before everything existed, the only thing that existed was this Pure Spirit, or it could be called God. In Hegel's view, the Pure Spirit could not understand himself (selfknowledge) because He has no comparison. Like a color, if it is white, then it cannot understand itself as white if there is no other color to compare to. In Hegel's dialectic, this is the thesis.

Because this Universal One has an intention to understand himself, He divides himself into various particular and physical entities, while the Pure Spirit is non-physical. The various particular entities are divided into two parts; the subject and the concrete object. These two entities contradict each other to understand the comparison, that the subject is not a concrete object, and vice versa. Therefore there are two kinds of words: the subject world and the object world. It is this tension between subject and object that gives birth to a dialectical history leading or evolving to a higher self-consciousness. In Hegel's view, the process is God himself. In Hegel's dialectic, this is the antithesis. Then, the synthesis is a unity between subject, object, and a more complex self-understanding (Sugiharto, 2016).

It is the outline of the structure of Hegel's philosophy that influenced most of the philosophers of the next period. The basic style built by Hegel seemed to be strange, particularly for Semitic religions, which usually deal with the issue of the creator and creatures. For Hegel, all these realities are the work of God himself, to then merge with him. In the world of religion, Hegel's thought is closer to the world of spirituality.

Hegel talks about art in very far-fetched detail as viewed from the broad outline of his philosophy. Art is discussed by Hegel when he talks about the Absolute Spirit. The Absolute Spirit itself is the result of a synthesis between the Subjective Spirit as the thesis, and the Objective Spirit as the anti-thesis. The dialectic between subjective spirit, objective spirit, and absolute spirit is discussed by Hegel in the philosophy of spirit. The philosophy of the Spirit itself is a synthesis. The thesis is the science of logic (thinking about ways of thinking), while the antithesis is natural philosophy (thinking about things outside oneself). From the two then emerged a synthesis called the philosophy of the Spirit. The dialectic between the sciences of logic, natural philosophy, and the philosophy of the spirit is raised by Hegel when he talks about the logic of historical development of the universe. From this map, it may be seen that the discussion of art in Hegel's philosophy lies in very far and complicated details. 
It is in this phase of the Absolute Spirit that Hegel asserts the Absolute Spirit is increasingly able to understand himself. Similar to Hegel's basic style of dialectics, this phase of Absolute Spirit is also divided into three; art (thesis), religion (anti-thesis), and philosophy (synthesis). In art, the Absolute Spirit is 'observed and articulated in forms'. In religion, the Absolute Spirit is 'understood in assumptions'. In philosophy, the Absolute Spirit is 'logically understood'. It is the peak of Hegel's philosophical structure on the logic of historical development of the universe or the peak of civilisation. In relation to the discussion in this paper, the most important point is that when talking about art, Hegel always relates it to the Absolute Spirit. Art is one way for the Absolute Spirit to understand himself.

For Hegel, art is not merely an imitation (mimesis) but a creative endeavor. The core point, in this case, is about creating. It is called creative because art unites ideas and phenomena, thoughts and reality, matter and form. For Hegel art is therefore not only a matter of beauty but there are many conceptual elements or ideas. There is even a concept of truth in it; the truth about the Spirit (Hauskeller, 2015, p. 53).

Art also develops dialectically. It was originally a symbolic art, as a thesis. This type of art originated in the Eastern world, while its medium form is architecture. The core value of this art is transcendence, so even though there are statues, the statues have been stylised (changed shape). This type of art is confronted with classical art, as an anti-thesis. This type of art is in Greco-Roman times, while its medium form is sculpture and painting. The core value of this art is the human world, so it is a matter of balance. Therefore the proportions get very tight. The peak of art is romantic art, as a synthesis. Hegel calls romantic art the peak because the core value is no longer physical, such as symbolic art and classical art, but an inner expression. Therefore the most adequate mediums in the romantic arts are music and literature. Because this type of art is in the inner field, romantic art becomes the climax of Hegel's philosophy of art (Sunarto, 2015, p. 80).

Looking at this dialectical process, one may assume that there is a process of dematerialisation. Initially, art was in the form of gigantic material (symbolic art), then reduced and proportional (classical art), then the material disappeared, only abstract appears (romantic art). The process of dematerialisation gave rise to Hegel's very famous adage; the death of art, or the end of art (James, 2009, p. 72). The most basic reason for the death of art is that since romantic, art has lost its subject matter. The subject matter of the Absolute Spirit was then taken over by religion. Art loses subject matter because of the limited media to express the complexity of the Absolute Spirit. The highest medium of art is the tone (music) and word (literature). This paper then tries to confront this dialectical theory of art to the sacred arts of Balinese Hinduism.

\section{Balinese Hinduism as an Invented Religion}

Balinese religion, at its originality, was not referred to as Hinduism. It was before the conquest of Bali by Majapahit. There were many names or religious sects in Bali since the 7th century, such as Shiva, Buddha, Shiva-Buddha, Vishnu, or Tantrism Buddhism. However, all religious sects were under the hegemony of the religion of Shiva Siddhanta after Bali was ruled by Majapahit. In the modern era, Balinese intellectuals have launched the idea of Hinduisation of Balinese religion. It is to reconcile Indian Hinduism and Balinese religion. Therefore, the Balinese religion is nowadays known as Hinduism. Some name it Hindu Dharma. The deepest structure of Balinese religion is worship to ancestral spirits as well as parts of natural forces, such as earth, sky, air, water, or fire. In Balinese culture, these natural forces undergo an osmosis process into goddesses, whose names are later adapted to the names of the Hindu goddesses. Several intellectuals polish the basis of this Balinese religion by coupling it with the name of Hindu. This effort succeeded in finding a unique identity: Balinese based on Hinduism. However, it should be realised that Balinese is not Hinduism, and vice versa, Hinduism is not Balinese (Wijaya, 2014, p. 150).

Balinese Hinduism was not immediately recognised by the Indonesian government to be part of the official state religions. It was referred to as a sect of belief. At the time, the state only recognised the existence of Islam, Catholicism, and Christianity as religions because they already had prophets and 
scriptures, while Balinese Hinduism did not have these kinds of stuff. The following is the journey of government recognition of Balinese Hinduism:

1. On December 26, 1950, the minister of religion, Masykur visited the Bali Regional Office and was accepted by I Gusti Bagus Sugriwa as a member of the Bali Regional Government Council. After a deep discussion between them, the Minister of Religion could verbally accept the reasons for Balinese Hinduism to be part of state religions.

2. On October 10, 1952, opposite to the previous utterance, the Minister of Religion said that the government could not officially recognise Balinese Hinduism due to abstention of regulations for it.

3. In mid-1953, the local government of Bali established the Bali Regional Autonomous Religion Bureau to regulate the implementation of the Balinese Hindu religion.

4. On June 29, 1958, there was a meeting between President Soekarno and several representatives of religious and social organisations of Bali. The main issue of discussion is the formation of a Balinese Hindu section in the Ministry of Religion of the Republic of Indonesia, similar to other religions such as Islam, Catholicism, and Christianity.

5. On September 5, 1958, a Decree of the Minister of Religion of the Republic of Indonesia was issued acknowledging the existence of Balinese Hinduism (Sukarma, 2015, pp. 34-35).

Due to the state law and regulation, Balinese Hinduism then was compiled in a framework consisting of seven chambers; the name of religion, the name of God, Sradha, holy people, holy books, implementation, and holidays. The name of religion is Balinese Hinduism. The name of the Balinese Hinduism God is Sang Hyang Widhi, who has 23 titles. Sradha of Balinese Hinduism is 'AUM Sat Tat Ekam Ewa Adwityam'. This means that Sang Hyang Widhi Wasa, the Most Perfect, is only one. The most important Balinese Hindu holy person is Ordinary Bhagava, known as Krishna Dwipayana. The holy book of Balinese Hinduism is Sastra-Dharma, consisting of Veda-Sruti and Dharma-Sastra Smerti. The implementation of Balinese Hinduism is called Dharma, consisting of Sila and Yadnya. Balinese Hindu religious holidays are Nyepi, Pagerwesi, Galungan, Kuningan, and Saraswati.

Based on this description, the deep structure of Balinese religion does not change; worship to ancestor and natural forces. The changes occur in the external structure, such as symbols, prophets, holy books, and the implementation of Balinese Hinduism. These elements are taken from Hinduism. It can be said that external challenges and political interests are the main issues in this case; following Pancasila and the Indonesian government. Some say that this kind of Hinduism is recreated in the image of Islam (McDaniel, 2010). Therefore, Balinese Hinduism might be called an invented tradition; a religion that was invented, built, and officially realised.

\section{The Philosophy of Balinese Hindu Art}

Art is the result artist's taste, creativity, and initiative that cannot be separated from the bonds of noble cultural values, including aesthetics that live and develop in the community. Balinese art which is the result of the creativity of artists with Balinese culture is certainly full of aesthetic content that is imbued with cultural values bound by Balinese Hinduism. In this regard, the issue of cosmology should be considered which is closely related to Hindu aesthetics. Balinese people cosmologically view the universe as an orderly and balanced system. Cosmology is interpreted as order and harmony manifested in both macrocosm and microcosm (Arsana, 2014, p. 116). In this kind of cosmology, the universe is regarded as not only a physical (sekala) entity, but also spiritual (niskala). The macrocosm of the universe will continue to exist and be maintained as long as its elements are still controlled by the laws of order and balance. In daily life, Balinese people are always oriented to this balance. It is preserved by performing ritual ceremonies and ethics in social relations; harmonious relationships with Hyang Widhi, the natural environment, and fellow humans.

Hinduism is the most dominant element as well as the cultural spirit of Balinese society today. Every Balinese cultural creativity, including the arts, cannot be separated from both the ties of the noble values of Balinese culture itself and aesthetic values originating from Hinduism. Assessment of aesthetic quality is also determined by ethics or good-bad norms that apply in the cultural environment. 
The quality of beauty sometimes loses its meaning if there are elements contrary to existing ethics. Based on this consideration, many fundamental concepts are believed to be able to produce works of art that have supreme quality. The concepts that underlie the Balinese Hindu aesthetics include the concept of belief, the concept of sekala-niskala, the concept of tri hita karana, the concept of kala patra village, the concept of karmaphala, and the concept of taksu/jengah (Karthadinata, 2008).

The Concept of Belief

Balinese people have at least three kinds of belief: 1) a belief in sekala world (real) and niskala world (not real); 2) reincarnation; 3) life after death, as well as the presence of ancestral spirits. Humans may ask for protection from these ancestral spirits. With the power of niskala, the ancestral spirits may also give salvation to their descendants. Thus, the worship of ancestral spirits as practiced by the Balinese Hindu community today has existed and was known long before the arrival of Hinduism. Likewise in the field of art, at first it was a simple symbolic form. As Hinduism came, art becomes more developed, rich, dynamic, and complex, with higher aesthetic values and ideals. For Balinese people, physical and spiritual well-being can be achieved through the implementation of the main and fundamental concepts of Hinduism consistently that are oriented towards inner attitudes, behavior, and mindsets in daily life.

\section{The Concept of Sekala-Niskala}

This concept is to gain the ultimate goal of Hinduism is "Moksartham Jagadhita ya Caithi Dharma"; physical well-being and inner perfection. Through this concept, all Balinese human behaviors are measured by spiritual propriety. For example, a bucket that is usually used to wash underwear, on the view of sekala the bucket is clean, but in the view on niskala the bucket is not appropriate for drinking water or holy water. This concept makes Balinese people try to consider something behind reality.

\section{The Concept of Tri Hita Karana}

This ethics is to maintain harmony between human beings, humans and nature, and humans and their God. The Balinese were trained to know the right proportions in thinking, feeling, acting, and behaving. Balinese Hindus view the implementation of tasks and works as offerings to God. This view causes the Balinese to make a special place or ceremony before starting any activity. As they want to do any activity, including the arts, the Balinese strive to conduct a small ceremony to ask Hyang Widhi to witness the execution of work and provide safety for all performances and works. The formulation of Tat Twam Asi, which means I am you, is the principle of togetherness in Balinese society. Tat Twam Asi reflects the element of unity. This concept implies that helping others, as well as other creatures, is the same as helping oneself.

\section{The Concept of Kala Patra village}

This concept is unique because the implementation of religious teaching may differ in every region. The fundamental teachings should be the same, but the way of practice is always changing, based on the village (place), kala (time), and patra (circumstances). The concept urges the Balinese to not apply their local custom, but they have to be able to adapt to the local traditional customs. Based on this consideration, regions in Bali have different customs in performing religious ceremonies.

\section{The Concept Karmaphala}

It is the law of cause and effect. Karmaphala is divided into three types: Karmaphala Sancita Karmaphala Prarabda, and Karmaphala Kriyamana. The first Karmaphala is a reward for actions in previous lives that have not been fully enjoyed and still the seed that determines future lives. The second Karmaphala is a reward for actions in this life without any remainder. The third Karmaphala is a reward that is not enjoyed at the time of action which might be accepted in the next life. Through this awareness of time, Balinese Hindus are guided to think straightly, because what they are experiencing now cannot 
be separated from what was done previously. What they will experience in the future is very dependent on what they are doing now.

\section{The Concept of Taksu / Jengah}

Taksu is an inner power that gives intelligence, beauty, and magic. Based on various Balinese cultural activities, taksu also means pure cultural creativity, which gives an artist spiritual strength to express as bigger than his daily life. Taksu, playing an important role in various arts in Bali, is believed by Hindus in Bali to be an attractive force that appears in the artist or his/her art, after receiving the holy light from Hyang Widhi. Balinese people believe that an artistic presentation that does not have taksu will fail to attract the attention of the audience. Therefore, Taksu refers to the spiritual inspiration and energy within a mask, puppet, or character (Davies, 2007). In the context of Balinese art culture, Jengah has the connotation of a spirit to compete in creating high-quality works. Taksu has the meaning of cultural creativity, while Jengah is a dynamic trait possessed by the culture, which is a spiritual movement that is the basis of all changes in people's lives.

\section{The sacredness of Balinese Hindu Art: Hegel's 'The Death of Art' Theory Questioned}

The sacredness of Balinese Hindu art has been deeply guarded by the Balinese people. Various concepts and classifications are made to maintain sacredness. Balinese Hindu sacred art is an integral part of worship rituals in the context of offering or Yadnya to God. For the Balinese Hindu community, art is not a human but God's creation. Art is, therefore, presented to God. This concept is following the thought of George Wilhelm Friedrich Hegel (1770-1831). He placed art in the dialectic of the Absolute Spirit, along with religion and philosophy. It means that art is an attempt to translate the Absolute Spirit itself.

The question is how art articulates the abstract Absolute Spirit? How the concrete art reaches the non-material realm? Recent thinkers point out this one; a human experience. The world that is directly experienced is called the primary world. The primary world is the Life-world (Lebenswelt), the world that is directly experienced (lived world), the world of concrete coexistence before reflection, the world of which the shape is not clear (amorphous), and very complex. It is the world that transcends the Subject-Object category (Sugiharto, 2015, p. 16). The power of art lies in the complexity of human concrete experience. The power of art is to give shape to an experience that is unclear in form. Art is displaying the hidden one and articulating the untranslated. Art is, therefore, not talking about beauty but truth. The truth about the concrete human experience is complex, strange, unique, and ambiguous.

The truth revealed by art is a reality that is almost never in binary opposition. It reveals limitless things with even unimaginable possibilities. Thus, one of the important functions of art is the disclosive function, which allows the disclosure of various layers, complexities, and mysteries of reality to human consciousness (See further: Hardiman, 2015, pp. 97-202). The truth that art aims at is related to superficiality and depth, to be more civilised or not, to be wiser or not. Art is a unique experience of communication with and about anyone and anything, including the Mystery of Life, God. That is why at the deepest level, art is valuable and spiritual, religious, or even mystical (Sugiharto, 2015, p. 24; Sumardjo, 2000, p. 7).

Related to this consideration, the Balinese Hindu art has three concepts concerning holiness, truth, and balance (Karthadinata, 2008).

1. The Concept of Holiness

Balinese Hindu religious leaders proclaim that God is the Most Beautiful and the source of all beauty. For this belief, they believe that everything that has artistic value is God's creation. Thus, Balinese Hindus believe that art is not a human but God's creation. For this reason, Hindus must offer back their creations. Art is, therefore, presented to God. All types of art that are an offering to God (yadnya) are categorised as sacred arts (Supartha, 2012). Balinese artists perform art as an offering to get closer to Hyang Widhi. Art can not only satisfy and fulfill personal or community aesthetic urges, but also as a vehicle for artists to get closer to the source of beauty itself, God 
having the attributes of satyam (truth), shiwan (holiness), and sundaram (beauty). This kind of art is divided into two groups: (1) wali arts (sacred religious art), and (2) bebali arts (ceremonial art). Wali art includes various forms of art that are classified as old and therefore have elements of authenticity and purity.

2. The Concept of Truth

Based on the teachings of Hinduism, the offerings and yadnya performed by the Hindu community in Bali are carried out with honesty, sincerity, and earnest intentions. The art performances are not to gain public sympathy, or a sense of self-interest to get a greater reward. The concept of truth is, therefore, includes the values of honesty and sincerity. Only based on this honesty that the offerings and yadnya made by the community will be accepted by God.

\section{The Concept of Balance}

The concept of balance in art is articulated in both two-dimensional and three-dimensional art. In two-dimensional art, the concept of balance produces both symmetrical and asymmetrical forms, or harmonious and disharmony relationships. This aesthetic reflection is called rwa bhineda. In the concept, the spirit of togetherness, the existence of interrelationships, and the competition create interaction and competition. In three-dimensional art, the concept of balance is closely related to the concept of Hindu cosmology which divides this world into three parts: upper, middle, and lower which is called tri bhuwana. The upper and lower realms are virtual (niskala), while the middle world is real (sekala), which is the world of humans and the universe. These all concepts influence the way Balinese artists use vertical space in their artwork.

To maintain the sacredness of Balinese Hindu art, Balinese people make a classification that distinguishes sacred and profane arts. In more detail, artists and culturalists in Bali classify art into three groups; wali art (sacred art that can only be performed during religious ceremonies), bebali art (semi-sacred art), and balih-balihan art (entertainment art). This classification was first formulated in 1971 to guide art policies in Bali (Suteja, 2010, p. 29). This classification is an effort to put art in its proper place. Some researchers say that Balinese Hindu art has transformed by changing sacred to profane arts due to the demands of tourism and the economy (Subrata, 2014). However, the transformation did not occur in entire aspects. If this transformation is regarded, the sacred arts then will disappear and all arts become profane. Although the inspiration for balih-balihan art (entertainment art) (Astini \& Utina, 2007) comes from sacred arts, it does not necessarily eliminate the existence of sacred arts. This sacred art still exists and is only performed at a sacred place and time.

The classification of art made by Balinese Hindus to maintain the existence of art amid the onslaught of global culture, by dividing art into wali, bebalih, and balih-balihan arts is, in my view, a force to reject Hegel's theory of 'the death of art'. Hegel's theory departs from the dialectical assumption of art; the process of dematerialisation. The most basic reason for the death of art is that since romantic, art has lost its subject matter. The subject matter of the absolute spirit was then taken over by religion. Art loses subject matter because of the limited media to express the complexity of the Absolute Spirit. Hegel's assumption does not happen to Balinese Hindus. Balinese Hindu sacred arts have not lost subject matter in expressing the uniqueness and complexity of the Absolute Spirit. The art of wali and bebalih is a concrete example. This sacred art remains an integral part of Balinese Hindu worship rituals until now. In Balinese Hindus, art and religion are one and inseparable. That is why I argue that the transformation of art does not occur in Balinese Hindu art, as assumed by several other researchers.

\section{Conclusion}

The above discussion is an effort to confront Hegel's theory of 'the death of art' and the sacred Balinese Hindu art. The classification of sacred and profane arts made by Balinese Hindus is to maintain the sacredness of art itself. Through the art of wali and bebalih, the Balinese Hindu art maintains its subject matter; to express the complexity of the Absolute Spirit, as suggested by Hegel. It is the wealth of indigenous beliefs in Indonesia to maintain its uniqueness to respond creatively to contemporary 
global challenges, as the argument of this paper. On the wider scope, various local beliefs spread throughout the archipelago have also their uniqueness to do the same.

\section{References}

Arsana, I. N. C. (2014). Kosmologis Tetabuhan dalam Upacara Ngaben. Jurnal Resital, 15(2).

Astini, S. M., \& Utina, U. T. (2007). Tari Pendet sebagai Tari Balih-Balihan. Harmonia Jurnal Pengetahuan Dan Pemikiran Seni, VIII(2).

Bertram, G. W. (2017). Why Does the End of Art Matter for Art in General? In A. Bertinetto \& G. Garelli (Eds.), Morte dell'arte e rinascita dell'immagine (pp. 19-29). Giugno.

Carter, C. (1980). A Re-examination of the "Death of Art" Interpretation of Hegel's Aesthetics. In W. E. Steinkraus \& K. I. Schmitz (Eds.), Art and Logic in Hegel's Philosophy (pp. 83-100). Humanities Press.

Davies, S. (2007). Balinese Aesthetics. The Journal of Aesthetics and Art Criticism, 65(1), 21-29.

Harahap, N. (2014). Penelitian Kepustakaan. Journal Iqra', 08(01).

Hardiman, F. B. (2015). Seni Memahami - Hermeneutik dari Schleiermacher sampai Derrida. Kanisius.

Hauskeller, M. (2015). Seni - Apa Itu? Posisi Estetika dari Platon sampai Danto (M. J. Wizemann \& S. Graha, Trans.). Kanisius.

Hegel, G. W. F. (1975a). Aesthetics: Lectures on Fine Art. Volume I (T. M. Knox, Trans.). Oxford University Press.

Hegel, G. W. F. (1975b). Aesthetics: Lectures on Fine Art. Volume II (T. M. Knox, Trans.). Oxford University Press.

Hegel, G. W. F. (1977). Phenomenology of Spirit (A. V. Miller, Trans.). Oxford University Press.

Hegel, G. W. F. (1991). The Philosophy of History (J. Sibree, Trans.). Prometheus Books.

Hegel, G. W. F. (2010). The Science of Logic (G. di Giovanni, Trans.). Cambridge University Press.

James, D. (2009). Art, Myth and Society in Hegel's Aesthetics. Continuum.

Karthadinata, D. M. (2008). Estetika Hindu Dalam Kesenian Bali. Jurnal Imajinasi, 4(1).

Keene, M. (2006). Agama-Agama Dunia. Kanisius.

Knott, K. (1998). Hinduism: A Very Short Introduction. Oxford University Press.

McDaniel, J. (2010). Agama Hindu Dharma Indonesia as a New Religious Movement: Hinduism Recreated in the Image of Islam. Nova Religio: The Journal of Alternative and Emergent Religions, 14(1), 93-111.

Miller, J. (2012). The 'Death of Art' and Painting the "Sunday of Life": Hegel on the Fate of Modern Art. Evental Aesthetics, 1(1), 39-47.

Otto, R. (1950). The Idea of the Holy. Oxford University Press.

Picard, M. (2011). Balinese religion in search of recognition: From "Agama Hindu Bali" to "Agama Hindu" (19451965). Bijdragen Tot de Taal-, Land- En Volkenkunde, 167(4), 482-510.

Subrata, I. W. (2014). Ideologi Komodifikasi Seni Pertunjukan Barong di Banjar Denjalan-Batur, Batubulan, Gianyar. http://ojs.unud.ac.id/index.php/ecs/ article/view/9732/7263

Sugiharto, B. (2015). Untuk Apa Seni? Matahari.

Sugiharto, B. (2016). Metafisika Kebudayaan (Vol. 4). Pustaka Matahari.

Sukarma, I. W. (2015). Sistem Ketuhanan Agama Hindu. Jurnal Jnana Budaya, 20(1).

Sumardjo, J. (2000). Filsafat Seni. Penerbit ITB.

Sunarto. (2015). Seni yang Absolut Menurut G.W.F. Hegel (1770-1831). Jurnal Imaji, 13(1).

Supartha, W. (2012). Bentuk dan Fungsi Pertunjukan Wayang Lemah dalam Kehidupan Religius Umat Hindu di Bali. Jurnal Widya Duta, 1.

Suteja, I. M. D. (2010). Seni Pertunjukan Tradisional Bali ke Kontemporer. Jurnal Jnana Budaya, VIII(15).

Weber, M. (1958). The Religion of India: The Sociology of Hinduism and Buddhism (H. H. Gerth \& D. Martindale, Trans.). The Free Press.

Wijaya, N. (2014). Apakah Agama Hindu Bali Modern Lahir dari Tantangan Pancasila dan Islam? Jurnal Kajian Bali, 04(01).

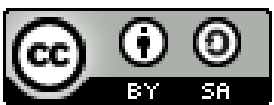

(C) 2021 by the authors. Submitted for possible open access publication under the terms and conditions of the Creative Commons Attribution (CC BY SA) license (https://creativecommons.org/licenses/by-sa/3.0/). 
This page is intentionally left blank 